\title{
Immobilized Carbohydrates and the Threshold Effect*
}

\author{
固 定 化 糖 と 闘 值 効 果 \\ Saul ROSEMAN \\ Department of Biology and the McCollum-Pratt Institute, The Johns Hopkins University, \\ Baltimore, MD 21218, USA, FAX: 1-301-338-5213
}

\section{A. Introduction}

In recent years, there has been an exponential growth of interest in the functions of cell surface glycoconjugates. Most of this effort has focussed on qualitative identification of the biologically active components, such as the carbohydrate ligands that bind cell surface lectins. However, there is a quantitative aspect to these phenomena that may be much more difficult to address, but that may be just as crucial if we are to begin to understand the behavior of intact cells.

\section{B. Immobilized Carbohydrates}

In 1973(1), in collaboration with Y. C. Lee, we began to use simple model systems as one method to test the hypothesis that carbohydrates were involved in intercellular recognition and adhesion. Sephadex beads were covalently derivatized with 6-aminohexyl $\beta$-D-glucopyranoside(AH-Glc), AH- $\beta$-DGal, AH- $\beta$-D-GlcNAc, and 6-aminohexanol as a control. The beads were mixed with suspensions of three types of tissue cultured cells, BHK, 3T3, and SV40 transformed 3T3 cells, and the suspensions were observed microscopically. There was no detectable effect with BHK cells, a slight effect with 3 T3 cells, but the results with SV40/3T3 cells were dramatic. Gal-beads, and only Gal-beads gave large mixed aggregates with the transformed cells in 15-60 min(Fig. 1), and it appeared as if the Galbeads triggered a nucleation phenomenon (discussed below).

While the results of these experiments were unambiguous, the technique did not lend itself to quantitation, and the next step was to improve the methodology. By then, we had turned to the use of freshly prepared rat and chicken hepatocytes to sudy specific cell-cell adhesion. For work on the model system, the ideal substrate would be a transparent, flat matrix to which the cells would not adhere unless the gel was covalently derivatized with the appropriate ligand. Poly-

\footnotetext{
* Supported by Grant GM 38927 from the National Institutes of Health. This is publication No. 1469 from the McCollum-Pratt Institute.
}

\section{A. はじめに}

近年、細胞表面の複合桾質の機能についての関心が急速に 高まってきている。それら研究の多くは、生物学的活性を持つ 分子、例えば細胞表層のレクチンに結合するリガンドである糖 鎖構造を同定するといった定性的なものである。しかしなが ら、これらの現象にはもちろん定量的側面もあり、解釈するの はより難しい。しかし、生きた細胞のふるまいを理解し始める と、それらが如何に重要な問題であるかが解ってこよう。

\section{B. 固定化糖}

我々は、Y.C.Leeとの共同研究として、1973年から、榶が 細胞間認識及び接着に関与しているという仮説を証明するため

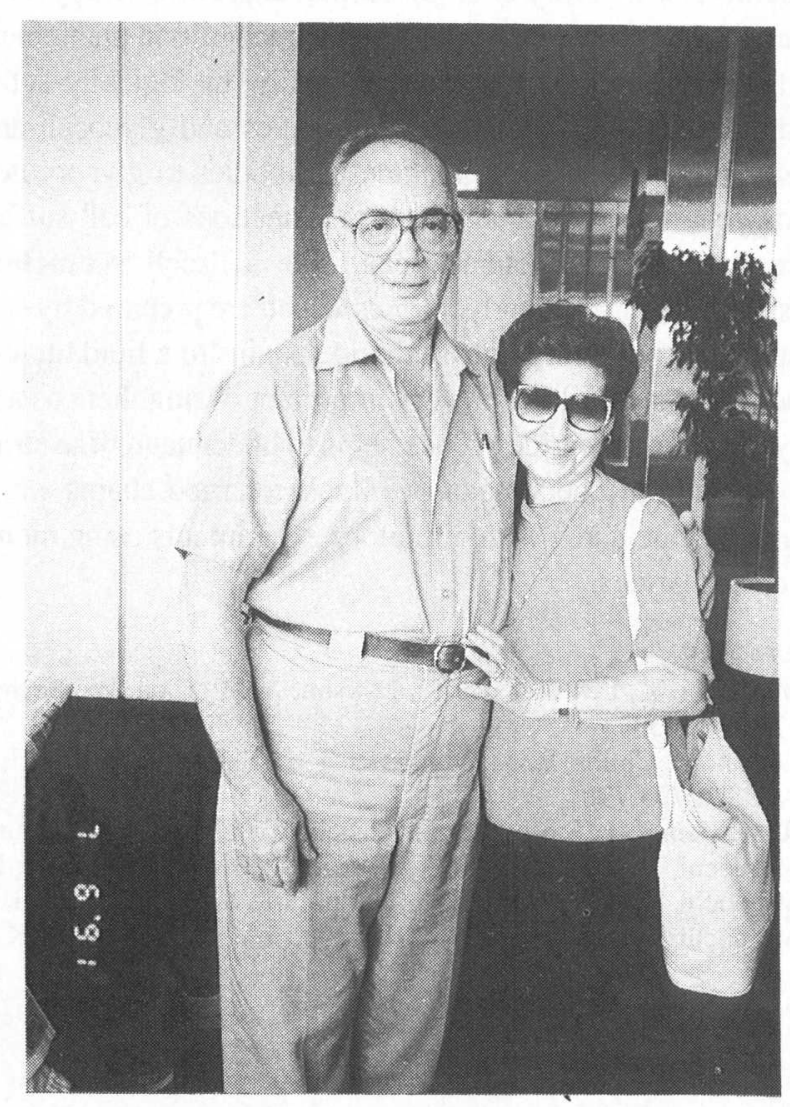

Dr. Saul Roseman and his wife, Martha at Toronto international airport on July 6, 1991. This picture was kindly contributed by Dr. Kiyoshi Furukawa, Institute of Medical Science, the University of Tokyo. 
TIGG Vol. 3 No.14 (November 1991)

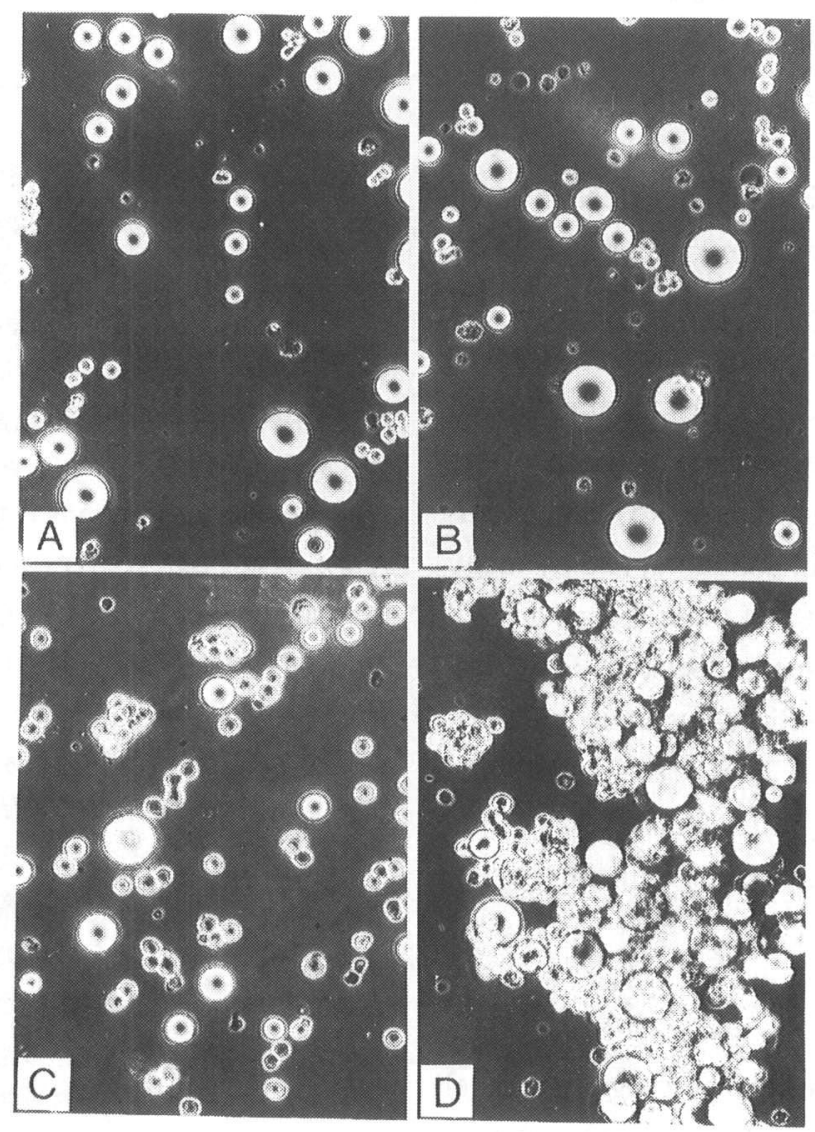

Fig. 1. Adhesion of SV40/3T3 cells to derivatized Sephadex beads. For conditions of growth, cell preparation, and assay, see(1). The cells and beads were incubated for $30 \mathrm{~min}$ at $37 \mathrm{C}$, and examined by phase contrast microscopy. The diameter of the beads varied from $10-40 \mu \mathrm{m}$. Cells plus: A, control beads; B, GlcNAc-derivatized beads; C, Glc-beads; D, Gal-beads.

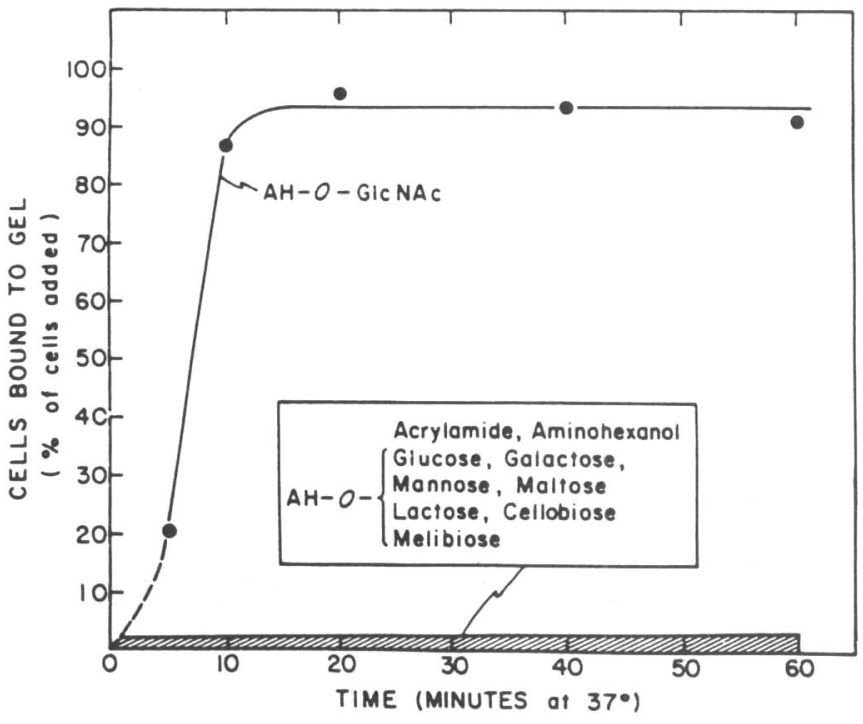

Fig. 2. Kinetics of chicken hepatocyte adhesion to derivatized polyacrylamide gels.

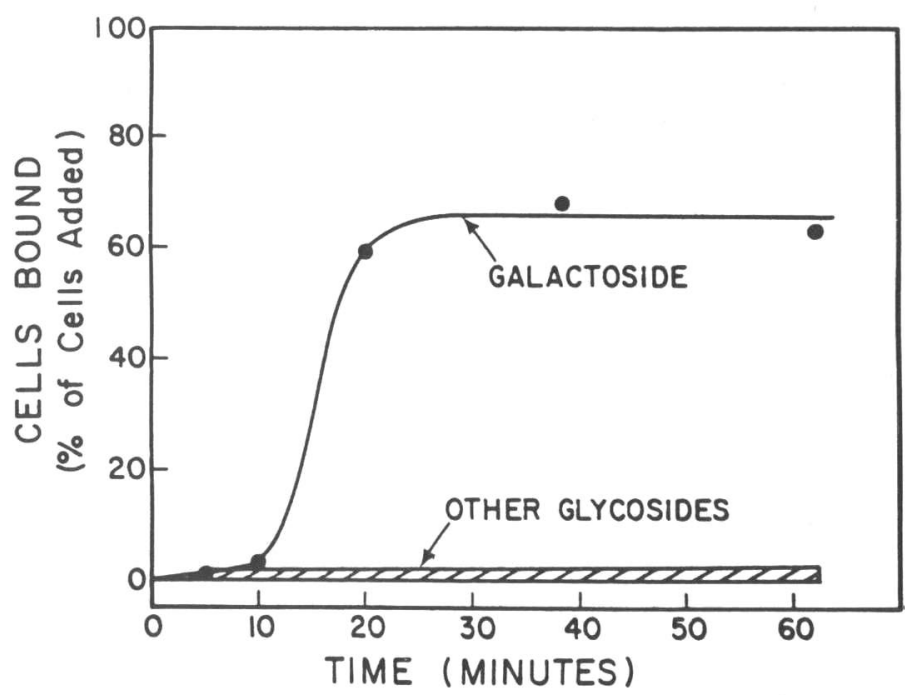

Fig. 3. Kinetics of rat hepatocyte adhesion to derivatized polyacrylamide gels. 
acrylamide gels exhibited precisely these properties $(2,3)$. Neither chicken nor rat hepatocytes adhered to the gels per se, but as shown in Figs. 2 and 3, strong binding was observedwhen the gels were derivatized with particular monosaccharides. The chicken hepatocytes adhered specifically to GlcNAc gels, while the rat hepatocytes showed the same kind of specificity towards Gal. [Appropriate glycoproteins and glycopeptides linked to polyacrylamide can also be used for these assays(4)]. The binding of the rat and chicken hepatocytes to immobilized Gal and GlcNAc is mediated by the respective hepatic receptors or lectins first reported by Morell and Ashwell(5), and extensively studied by Ashwell and his collaborators, and by many other laboratories. We later showed that these lectins are not involved in specific hepatocyte cell-cell adhesion. However, the binding of hepatocytes to immobilized sugars is an excellent model for the present discussion. That is, the model illustrates the potential physiological significance of what would normally appear to be slight quantitative changes in the concentrations of cell surface carbohydrates.

\section{The Threshold Effect}

When the concentration of immobilized sugar in the gel was varied, there was a dramatic effect on hepatocyte adhesion(Figs. 4 and 5). Below a certain (critical) concentration of immobilized sugar, there was no binding of cells to the gels. However, when the concentration was increased 10-20\%

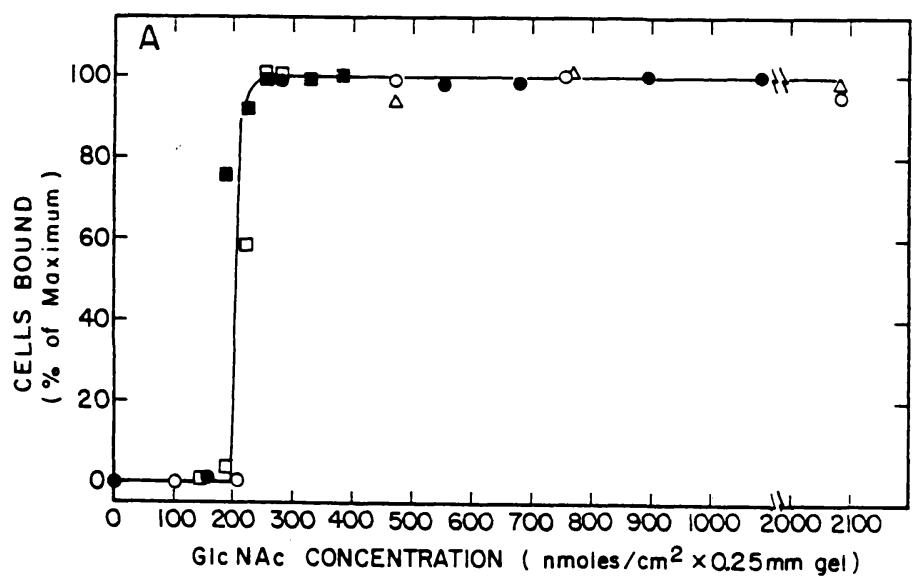

Fig. 4. Threshold binding response of chicken hepatocytes to GlcNAc-derivatized polyacrylamide gels. The symbols represent different cell preparations. Binding assays were conducted for $60 \mathrm{~min}$ at $37^{\circ} \mathrm{C}$.
のひとつの方法として単純なモデル系を使い始めた(1)。つま り、セファデックス・ビーズに、6-アミノヘキシル- $\beta$-D-グルコ ピラノース(AH-Glc)、6-アミノヘキシル- $\beta$-D-ガラクトピラノー ス(AH-Gal)、6-アミノヘキシル- $\beta$-D-N-アセチルグルコサミノ ビラノース(AH-GlcNAc)をそれぞれ共有䊅合させ、対照として は6-アミノへキサノールを共有䊅合させたものを調製した。そ して、ビーズをBHK細胞、3T3細胞、SV40で形質転換させた 3T3細胞の3種類の細胞培養液と混ぜて影微鏡下で観察した。 BHK細胞にはほとんど影䉕はなかったが、3T3細胞ではごく僅 かの、そしてSV40で形質転換させた $3 \mathrm{~T} 3$ 細胞では㩆著な変化が 認められた。ガラクトースを䊅合させたビーズ(Gal-ビース)と混 ぜた場合にのみ、15-60分で形質転換細胞は凝集して大きな細胞 の塊を形成し(図1)、あたかもGal-ビーズが核化現象(後述)の引 金を引いたかのように考えられた。

これら実験の䊅果は明白ではあったが、この方法自体に定 量性はなく、次には方法論の改良が必要であった。その時まで に、我々は特定の細胞間接着を研究するために、調製したての ラット及びニワトリの肝実質細胞を用いるようになっていた。 また、モデル采として用いるためには、適切なリガンドを共有 䊅合させない限り細胞の接着することのない透明で平らな基材 が理想的であると考えられた。ポリアクリルアミド・ゲルは、 まさにこのような性質を持つ $(2,3)$ 。ニワトリ肝実質細胞もラッ 卜肝実質細胞も、ゲルそのものには接着を示さず、図2及び3に 示す通り、ゲルに特定の単桾を共有䊅合させたときに強い接着 が観察された。ニワトリ肝実質細胞はGlcNAcを䊅合させたゲル に特異的に接着を示したが、ラット肝実質細胞も同様にGalを䊅 合させたゲルに特異的に䊅合させたにこのアッセイには、ゲルに 適切な榶蛋白質や糖ペプチドを䊅合させて用いることもできる

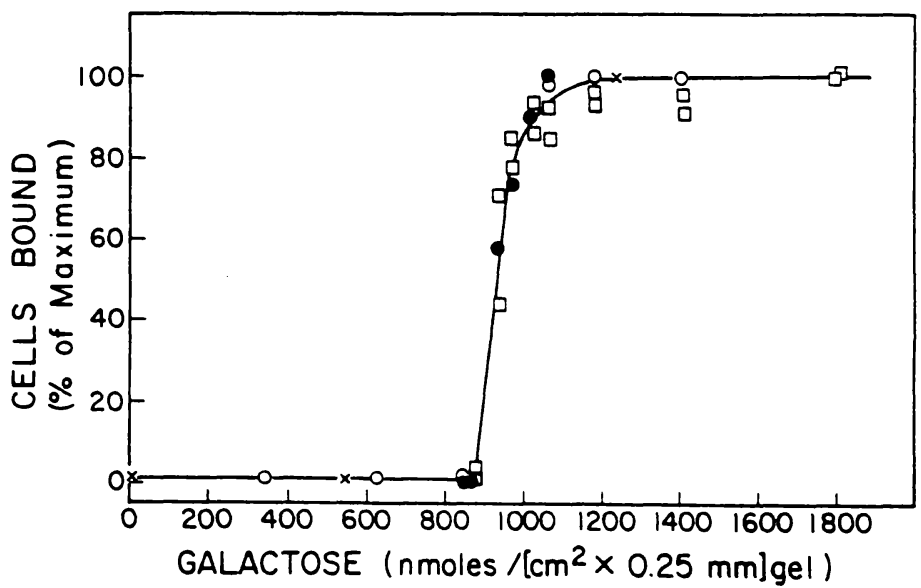

Fig. 5. Threshold binding response of rat hepatocytes to Gal-derivatized polyacrylamide gels. Same conditions as Fig. 4. 
above the critical value, cell binding was close to $100 \%$ of the maximum attained with each cell preparation. This kind of a threshold response had not been observed with carbohydrates, although intact cells do exhibit threshold phenomena with other ligands, such as hormones. However, responses to hormones usually require an order of magnitude (or greater) increase in the level above the critical concentration, not a $10-20 \%$ increase as shown in Figs. 4 and 5. A similar threshold effect was observed in the binding of hepatocytes to glycolipids adsorbed to plastic wells(6).

\section{Receptor Clustering}

Before discussing the mechanism of the threshold response, it is important to emphasize that the formation of stable cell-gel bonds is not a simple process. A method was developed for measuring the strength of binding of cells to sugarderivatized gels(7), and it was shown that two discrete steps are involved. The first, or "weak" binding, is energy independent. The second step involves a 15-fold increase (or more) in cellgel bond strength; this "strong" binding occurs after a lag period, and requires metabolic energy. [The two steps are remarkably similar to the two steps that occur in cell-cell adhe$\operatorname{sion}(8)]$.

What is the mechanism of the threshold response? Several possibilities were suggested(3), and one of these has been demonstrated. The rat hepatic lectin(RHL) forms patches on the cell surface when it binds to synthetic galactosides(9).

Recent studies(10) have greatly extended these observations: (a)RHL adhesion patches are circular when the cells bind to $\mathrm{AH}-\mathrm{Gal}$ or to covalently linked asialofetuin. The adhesion patch represents only about $8 \%$ of the cell surface membrane, yet all of the surface RHL diffuses in the plane of the membrane into the AH-Gal patch within minutes, even at $4^{\circ} \mathrm{C}$. When the ligand is asialofetuin, steric hindrance apparently prevents all of the RHL from sequestering into the adhesion patch. (b)Despite recruitment of all of the surface RHL into the adhesive patch, the total number of surface RHL molecules remains constant on Gal-adherent hepatocytes, and a large portion continues to recycle between intracellular and cell surface pools. (c)Patching of RHL is observed during the first step in cell-gel binding, i. e., "weak" binding. The second step, "strengthening" of the adhesion patch, appears to be related to the distribution of cytoskeletal elements, which must somehow be linked to surface RHL(11). This leads to control of cell morphology
(4)］。ラット肝実質細胞やニワトリ肝実質細胞の、それぞれ Gal PGlcNAcを固定化させたゲルへの結合は肝実質細胞のレセブタ ールクチンによるものである。この肝実質細胞レセプターのレ クチンは、Morell と Ashwellによって最初に報告され(5)、その後 も Ashwellのグループや他のグループによって解明されてきたも のである。しかし、肝実質細胞と肝実質細胞との間の接着につ いては、我々は後にこれらレクチンによるもののではないこと を示した。何れにしろ、細胞表面の相互作用の定量化という目 的には、固定化した糖への肝実質細胞の結合は優れたモデルと 言えよう。つまり、本モデルによって、細胞表層の糖の僅かな 量的変化によって生じる変化の潜在的な生理学的意義を示すこ とができるのである。

\section{C. 䦣值効果}

ゲルに固定化させた糖の量を変えると、肝実質細胞の接着 は劇的に変化した(図4及び図5)。固定化させた糖の分量が、或 る特定の值(臨界值)以下であると細胞のゲルへの䊅合は見られ ない。しかし、臨界値を10-20\%上回っただけで、細胞の結合は それぞれの細胞で認められる最大の結合のほとんど100\%近い䊅 合を示した。この種の闒值現象は、糖の関与する反応ではいま まで見られていないが、生きた細胞では他のリガンド、例えば ホルモンなどに対する反応に認められる。しかし、ホルモンへ の反応は、図4と図5に示した場合のように臨界値を10-20\%上 回ったときにではなく、通常一桁以上ホルモン浱度が増加した 際に生じるものである。同様な閥値効果は、糖脂質を吸着させ たブラスチック容器に対する肝実質細胞の結合においても認め られた(6)。

\section{D.レセプターの集合化(Clustering)}

閥值効果の機序について述べる前に、細胞とゲルとの安定 な結合の形成はひとつの単純なブロセスではないことを強調し ておく必要がある。糖を結合させたゲルへの細胞の䊅合の強さ を測定する方法(7)によって、このプロセスが明確に異なったふ たつのブロセスから構成されていることが判明した。最初のフ ロ七スは、"弱い"䊅合でエネルギー非依存性である。次のプロ セスでは、細胞とゲルとの結合力は15倍以上に強化され、この "強い"結合にはラグの時間と代謝エネルギーを必要とする[これ ら二つのプロセスは、細胞と細胞との間の接着において見られ る二つのプロセスと極めて類似している(8)]。

それでは、この閥值効果はどのようなメカニズムに基づく のであろうか？この問いに対して、幾つかの可能性が示され た(3)。それらのひとつは、ラット肝細胞のレクチン(RHL: Rat Hepatic Lectin)が合成ガラクトシドを䊅合したとき、細胞表面に 集合してパッチを形成する(9)という現象が見い出されたことに 基づいている。

近年の研究(10)によって、次のような事実が明らかにされ た； (a)ラット肝実質細胞が、ゲルに共有結合させたAH-Galもし 
by the molecular nature of the adhesive interaction. Cells that bind to either high or low molecular weight Gal-ligands are spherical and adhere via a circular patch, whereas when the same cells bind to immobilized peptide sequences(Arg-GlyAsp), they are more flattened and adhere via larger and irregularly shaped membrane patches. This again suggests a link between the cytoskeleton (and therefore the morphology) and the cell surface receptors.

Thus, we are beginning to understand what happens to cell surface receptors when they interact with their carbohydrate ligands. What is not yet clear, however, is why a $10-20 \%$ change in net concentration of the immobilized ligand triggers cell binding.

\section{E. Carbohydrate Clustering}

Two independent methods were used to synthesize the carbohydrate derivatized gels, and we assume that the carbohydrate ligands are randomly distributed over the surface of the gels. But this assumption may be wrong. It may be that intermolecular associations results in a "clustering" effect. This effect would become more pronounced as the concentration of the monomeric acryloyl derivative is increased. ${ }^{1}$

While the idea of intermolecular clustering of the sugars in the gels is purely speculative, the effects of intramolecular carbohydrate clustering on the binding of such ligands to animal lectins is well established(12) provided that the spacing between monosaccharides is optimized to permit binding of each of the sugars in the multivalent ligand. Under such conditions, the binding affinity to solubilized RHL increases from 600 to 1,000 -fold as the ligands contain one, two, or three appropriately spaced $\mathrm{Gal}$ or GalNAc residues, and the affinities increase from 20,000 to 50,000 -fold for the same series of compounds using intact rat hepatocytes. Thus, huge increases in binding constants resulted from intramolecular carbohydrate clustering. ${ }^{2}$

Since the distances between immobilized monosaccharide ligands in the gels is limited to rotation around bonds

${ }^{1}$ The synthesis of Type I gels involved the copolymerization of acrylamide and bisacrylamide with the acrylate ester of $N$-hydroxy succinimide; the activated gels were then reacted with AH-glycosides. Type II gels were synthesized using the $N$-acryloyl derivatives of the $\mathrm{AH}$-glycosides as the monomers during copolymerization. In both cases, block polymerization could have occurred, giving a nonrandom distribution of the ligands on the gel surface. This would be especially true if the monomers formed micelles; small changes around the CMC of the monomers would have large effects on the random or non-random disribution of the sugars in the final products.
くはアシアロフェッインへ結合したとき、RHLのパッチは環状 となる。パッチは細胞表面膜のたった $8 \%$ しか占めていないが、 表面膜にある全てのRHLは、たとえ $4{ }^{\circ} \mathrm{C}$ 条件下でも、数分間 のうちにパッチ部位に集まってくる。しかし、リガンドがアシ アロフェツインの場合には、立体障害のために全てのRHLが パッチ部位に集まって来ることはできない。(b)細胞表面の全て のRHLがパッチ部位へ集まって来るが、RHLの数自体には変化 はなく、そのほとんどは細胞内プールと細胞表面との間でリサ イクルされている。(c)RHLのパッチの形成は、細胞とゲルの間 の最初の反応、つまり"弱い"䊅合の時に観察される。接着パッ チが"強化"される第二プロセスでは、細胞表面のRHLとなんら かの形でリンクしていると考えられる細胞骨格エレメントの分 布が変わる(11)。このことから、細胞接着相互作用によって何 故細胞形態が変化するかが解る。ガラクトースをリガンドとし た場合、リガンドの分子量が大きくても小さくても、それに結 合した細胞は球形となり、環状パッチを介して接着する。しか し、同じ細胞が固定化したArg-Gly-Aspの配列を持つペプチドに 結合する場合には、細胞はより平らな形となり、より大きく不 規則な形のパッチを介して接着する。このことは、細胞骨格(つ まり、細胞形態)と細胞表面レセプターとの間の関連を示唆する ものである。

このように、細胞表面のレセプターが対応するリガンドで ある糖と作用するとき、我々は細胞表面のレセプターに何が起 こるのかを理解し始めている。しかし、それでも何故、固定化 したリガンドの量がほんの10-20\%変化しただけで細胞接着の引 き金が引かれるのかは明らかではない。

\section{E. 糖の集合化(Clustering)}

ゲルへの糖の結合には2種類の方法を用いたが、それらの 方法によってはリガンドである糖はゲル表面に均一に分布する と仮定している。しかし、この仮定はもしかしたら間違ってい るのかもしれない。つまり、分子間会合が原因してリガンドの 集合化があるかもしれない。これは、単量体のアクリル誘導体 濃度を增加させることで顕著となろう(注1)。

ゲル上での糖の分子間集合化は単に推測ではあるが、糖分 子が分子内集合することで、リガンドである糖の動物細胞レク チンへの結合が影響されることはよく知られている(12)。つま ク、多価の結合部位をもつリガンド糖では、認識される単糖 各々の間の分子内での距離はその結合が最適となるように保た れている。そのような条件下、リガンドが適切な距離をもって

注1) 型ゲルとして用いたものはアクリルアミドとビスアクリスアミド とをN-ヒドロキシサクシニミドのアクリル酸エステル存在下で共重合さ せて調製し、活性化したゲルを更にAH-配糖体と反応させた。II型ゲル はN-アクリル化AH糖を単量体として共重合して調製した。何れの場合 も、部分的重合が生じる可能性があり、ゲル表面にリガンドが不均等に 分布する原因となろう。特に、単量体がミセルを形成する場合、単量体 の臨界ミセル濃度(CMC)付近で生じた僅かな変化は、最終産物の糖の分 布がランダムな分布をとるか否かに大きな影瞥を与えるであろう。 
rather than by diffusion (as occurs in solution), then intermolecular clustering of immobilized sugars would have the same general effect as fixing the distances between these ligands intramolecularly. In other words, intermolecular clustering could lead to a huge increase in binding affinities to the membrane lectins.

Clustering of at least some glycoconjugates occurs insynthetic and natural membranes. The distribution of glycolipids in synthetic phospholipid bilayers has been studied in detail by Thompson et al.(13). Some glycolipids form distinct domains, i. e., "clusters", within the bilayer, although it should be emphasized that the individual molecules are free to move laterally within the phosphatidylcholine bilayer. The same kind of clustering has been found for various glycolipids in natural membranes. For instance, globoside and the Forssman antigen each formed clusters in erythrocyte ghosts(14), although it was necessary to treat human erythrocyte ghosts with trypsin in order to expose the glycolipids to the antibodies.

Thus, glycolipids can form clusters in the membrane, and the major erythrocyte glycoprotein also forms clusters(14). One obvious problem that lies in the future will be to determine the normal distribution of ligands that are capable of clustering.

\section{F. The Nucleation Effect; Cascades?}

Figure 1 shows one set of results that merits much closer study. When the SV40/3T3 cells adhered to the Gal-beads, it triggered an apparent nucleation effect. The cells on the beads became much more adhesive for cells in suspension, so that the final result was the formation of huge aggregates of cells and beads.

The probable mechanisms underlying affinity of these cells for Gal-beads has been discussed above although the SV40/3T3 lectin may or may not be similar to RHL. However, there is no obvious explanation for increased affinity of the cells for each other. The binding of SV40/3T3 cells to beads may have triggered the appearance of additional $\mathrm{Gal}$ or lectin groups on the cell surface, or a redistribution of existing ligands and/or receptors, or the appearance of a new sets of interactive molecules, independent of $\mathrm{Gal}$ and its lectin.

While the mechanism of the nucleation effect has not

${ }^{2}$ Receptor clustering is also evident in the experiments of Lee, et al.(12). Clustering of RHL in the intact cell membranes explains the 40-50 fold increased affinity for a given ligand when the intact cell data are compared to the results with the solubilized receptor.
隔たった1個、2個または3個のGal残基もしくはGalNAc残基を持 てば、可溶化したRHLへの䊅合の親和性は600倍から1,000倍に 增加する。また、生きたラットの肝実質細胞を用いたときに は、同じリガンドに対して、20,000倍から50,000倍に增加す る。このように大きな䊅合定数の增加は、分子内における榶の 集合化に起因しているのである(注2)。

ゲル上に単糖から成るリガンドを固定化させたときの単榶 間の距離は、溶液中で見られるように拡散によるのではなく䊅 合軸のまわりの回転によって制限されるので、固定化された糖 が分子間集合するということは、分子内で距離を固定するのと 同じ効果となる。言い換えれば、分子間での集合化も膜にある レクチンへの䊅合の親和力を大きく增大させる。

少なくとも或る種の複合榶質は、人工膜や天然生体膜で集 合していることが知られている。人工燐質二重膜での糖脂質 の分布については、Thompsonらによって詳細に検討されてきた (13)。個々の分子はホスファチジルコリンの二重膜内で即面方 向には自由に移動できるのに、特定の領域、即ち"集合(Cluster)" を形成する榶脂質がある。天然の生体膜においても種々の榶脂 質で同様な集合が見られる。例えば、グロボシドやForssman抗 原は、ヒト赤血球ゴースト膜でそれぞれ集合を形成する(14)。 但し、そのような集合は赤血球ゴースト膜をトリプシン処理し なければ、それぞれに対する抗体に懪されないので検出できな w。

このように糖脂質は膜内で集合を形成しており、また赤血 球の主要な糖蛋白質も集合を形成していることが知られている (14)。しかし、集合を形成できるリガンドが通常、如何なる分 布をとっているかについては今後の課題として残されている。

\section{F. 核化効果 ; カスケード効果か ?}

図1の実験䊅果については、より綿密に検討するに值しよ う。SV40/3T3細胞はゲル・ビースに接着すると顥著な核化効果 を示す。つまり、細胞がビーズに接着すると、更に遊離細胞に 対して接着性を增すので、䊅果としては巨大な細胞とビースの 塊が形成される。

SV40/3T3細胞のレクチンがRHLと同様であるか否かはと もかくとして、前述したような細胞のGal-ビーズへの親和性で この現象は説明できよう。しかし、細胞間の親和力の上昇につ いては説明できない。SV40/3T3細胞のビーズへの䊅合は、細胞 表面にGal残基もしくはレクチンを増加させるような、もしくは 既存のリガンドもしくはレセブターの分布を変化させるよう な、また、もしくはGal残基やそれに対するレクチンとは異なる 相互作用に関わる新たな分子を出現させるような引金を引くの かもしれない。

注2) Leeらの実験(12)により、レセプターの集合化が起こることも明ら かである。生きた細胞でのRHLの集合化は、可溶化レセブターを用いた 実験データと比較すると、或る特定のリガンドに対する親和力を 40-50 倍增加させる。 
been resolved, it is important to emphasize that the binding of even simple immobilized carbohydrates by intact cells can have global consequences on cell physiology, presumably mediated by intracellular cascades.

\section{G. Conclusions and Problems}

The first question, of course, is whether the model system described above is relevant to what actually occurs in vivo. Although the question cannot be answered at this time, it it of interest to note that the list of cell surface lectins is growing rapidly, as is the list of their ligands(15), many of which are glycolipids. For the remainder of this discussion we shall assume that the threshold response can and does occur in vivo.

The fundamental point is that a threshold response means an all or none qualitative response in cell behavior to a small, apparently insignificant quantitative change in composition or distribution of ligands on the cell surface.

Quantitative, as well as qualitative changes in the carbohydrate composition of cell surfaces are known to occur during the cell cycle, and when normal cells are transformed. While these changes are not very large, they may be of great importance if they occur around the relevant critical concentrations [see Discussion in (3)].

The problem will be how to detect, measure and evaluate changes that may be in the range of $10-20 \%$. Aside from small differences in the total quantity of a given ligand, differnences which may often lie within the errors of the measurements, there will problems of measuring accessible versus cryptic ligands, and clustering versus radom distribution. On top of these exceedingly difficult analytical problems, it will be necessary to show that the reagents themselves do not perturb the distribution of ligands in the membrane. A new generation of highly specific, high affinity carbohydrate-specific probes will be required to make such measurements. Sugar-specific enzymes, lectins, and antibodies are fine as far as they go, but steric factors on cell surfaces, steric factors introduced by the reagents themselves $(10,11)$, and perturbations of glycoconjugate distribution in the membrane by these multivalent reagents may well preclude accurate analyses of the surfaces of interest. Now that X-ray crystallographic data are providing precise structures of the binding sites of sugar-lectin complexes, it may be possible to design very small, monovalent polypeptides of defined and fixed molecular dimension that meet the necessary requirements. This indeed would be a new generation of carbo-
核化効果がどうして起こるのかは未だ明らかではないが、 生きた細胞が固定化した糖を䊅合するという単純な現。たさ え、おそらく細胞内のカスケードを通して細胞生理学的特性に 大きな影響を与えるのであるということをここでは強調してお きたい。

\section{G. 結論及び問点点}

当然生じてくる最初の問いとしては、ここで用いたモデル 系がin vivoで実際に起きていることをどれだけ反映しているか という問題である。現時点ではこの問いに対する回答はできな い。しかし、細胞表面に様々なレクチンとそのリガンドが次タ に見い出されており(15)、その多くが糖脂質であることは注目 に值する。ここでは、閥值現象がin vivoでも生じるのだと仮定 して以下の釉論を進めよう。

閾值現象とは、細胞表面のリガンドの組成や分布に小さな 量的変化が生じたことに対して、細胞が全か無かの量的ふるま いをとることである。

細胞表面の構成榶における量的・質的変化は、細胞周期に おいて、また細胞が形質転換されたときに起きることが知られ ている。その变化自体は大きなものではないが、それが特定の 臨界洤度の近辺で生じたときには重要な意味を持っことになる [文献(3)の考察を参照]。

問題は、どうやって10-20\%といった小さな幅の変化を検 出、測定、評価するかという点にある。ひとつのリガンドの絶 対量における僅かの差異は湘定方法の誤差範囲内であることが 多々あるが、ここで言っているのは、レセプターに近づくこと の出来るリガンドと隠されたリガンドとを、また集合した状態 とランタムに分布した状態とを測定する方法である。このよう な分析手法自体が極めて難しいことに加えて、用いる試薬自体 が膜上でのリガンドの分布に影響を与えないかといった点も重 要である。糖に対して高度に選択的で高い親和力をもった新し いプローブをこのような測定系には用いる必要があろう。榶特 異的酳素、レクチン、抗体といった道具は、それ自体に問題は ない。しかし、細胞表面の立体要因、試薬によって生じる立体 障害 $(10,11) 、$ 多価の反応性を持つ試薬によって生じる膜上での 複合糖質の分布の変化などは、対象とする膜表面の正確な分析 に障害を及はそう。現在では、糖とレクチンの複合体の䊅合部 位の正確な構造がX線解析によって得られるようになってきた ので、この問題の解決に必要な要求を涌たすような小さく、単 価の䊅合部位しか持たない分子の設計が可能となってきてい る。このようなアプローチで、新しい糖特異的プローブを生み 出すことが可能かもしれない。

本エッセイは、生理学的には、細胞表面は我々が想像して きたよりもはるかに構造的・機能的に複雑であると、極めて単 純な要約にすることができよう。では、それはどういうことな のか。Phillip Rothの小説、"Portnoy's Complaint"の最後に登場す る精神科医に言ってもらおう。「そう。さて、そろそろ解りかけ 
hydrate-specific probes.

One can summarize this essay very simply. In a physiological sense, the cell surface is structurally and functionally much more complex than we had ever envisioned. Now what?

To paraphrase the psychiatrist at the conclusion of Portnoy's

Complaint, "So. Now we may perhaps begin. Yes?"
てきたから始めることにしょうか。」

中外製薬株式会社 研開企画部

田中 徹三 訳

\section{References}

1. Chipowsky, S., Lee, Y. C., and Roseman, S.(1973) Proc. Natl. Acad. Sci. USA 70, 2309-2312

2. Schanaar, R. L., Weigel, P. H., Kuhlenschmidt, M. S., Lee, Y. C., and Roseman, S.(1978) J. Biol. Chem. 253,7940-7951

3. Weigel, P. H., Schnaar, R. L., Kuhlenschmidt, M. S. Schmell, E., Lee, R. T., Lee, Y. C. , and Roseman, S.(1979) J. Biol. Chem. 254, $10830-10838$

4. Pless, D. D., Lee., Y. C., Roseman, S., and Schnaar, R. L.(1983) J. Biol. Chem. 258, 2340-2349

5. Ashwell, G., and Morell, A. G.(1974) Adv. Enzymol. Relat. Areas Mol. Biol. 41, 99-128

6. Blackburn, C. C., and Schnaar, R. L.(1983) J. Biol. Chem. 258, 1180-1186

7. Guamaccia, S. P., and Schnaar, R. L.(1982) J. Biol. Chem. 257, 14288-14292

8. Umbreit, J., and Roseman, S.(1975) J. Biol. Chem. 250, 9360-9368

9. Weigel, P. H.(1980) J. Cell Biol. 87, 855-861

10.Weisz, O. A., and Schnaar, R. L.(1991) J. Cell Biol. in the press

11. Weisz, O. A., and Schnaar, R. L.(1991) J. Cell Biol. in the press

12. Lee, Y. C., Lee, R. T., Rice, K., Ichikawa, Y., and Wong, T.(1991) Pure Appl. Chem. 63, 499-506

13. Thompson, T. E., and Tillack, T. W.(1985) Ann. Rev. Biophys. 14, 361-386

14. Tillack, T. W., Allietta, M., Moran, R. E., and Young, W. W.(1983) Biochim. Biophys. Acta 733, 15-24

15. Abstracts of the 11th International Symposium on Glycoconjugates (1991),Toronto, Canada, Glycoconj. J. 8, No. 3, 125-318

\section{TIGG is the Best Journal for Advertising Glyco-products and Glyco-books!!!}

\section{ADVERTISING INFORMATION}

Style of TIGG: Letter Size

Number of Printed Issues: 1,500

Method of Printing: Offset Lithographic

Manuscript: Black and White, Camera Ready Artwork

Date of Issue: 2nd of Odd-numbered Month

Copy Deadline: 25th of Odd-numbered Month

Mechanical Data:

$$
\begin{aligned}
& \text { Type Area } 254 \mathrm{~mm} \times 178 \mathrm{~mm} \\
& \text { 1/2 Page } 124 \mathrm{~mm} \times 178 \mathrm{~mm}, 254 \mathrm{~mm} \times 88 \mathrm{~mm}
\end{aligned}
$$

Rates:

$\begin{array}{lr}\text { Outside Back Cover } & ¥ 150,000 \\ \text { Inside Front Cover } & ¥ 80,000 \\ \text { Inside Back Cover } & ¥ 70,000 \\ \text { Facing Matter(One Page) } & ¥ 50,000 \\ \text { Facing Matter(1/2 Page) } & ¥ 30,000\end{array}$

Contact Advertising Department, FCCA.

3-10-1 Koufudai, Fujishiro-cho, Kitasouma-gun, Ibaraki-ken 300-15, Japan (Phone: 81-297-83-7635, Telefax: 81-297-83-7645) 